\title{
Level of Knowledge, Attitude, and Behavior of Housewives about Mosquito Nest Eradication in Bali 2017
}

\author{
M B T Ariawan ${ }^{1}$, G R A Herryadi ${ }^{1}$, P A N K Permatananda ${ }^{1^{*}}$ \\ ${ }^{1}$ Faculty of Medicine and Health Science, Universitas Warmadewa, Indonesia \\ *nayakasih@gmail.com
}

\begin{abstract}
Dengue Hemorrhagic Fever (DHF) is still a health problem in the world including Indonesia. The number of dengue fever cases continues to increase in Gianyar Regency, Bali. This is not separated from the role of housewives in taking care of the house. The purpose of this research is to know the level of knowledge, attitude and behavior of housewife about mosquito nests eradication in Gianyar Regency in 2017. This research is a descriptive research conducted by using cross sectional method. The sample of this study is 106 housewives selected by multistage random sampling method. The results of this research indicates that the knowledge rates of housewives about mosquito nests eradication is enough $50.9 \%$, less $29.2 \%$, and good $19.8 \%$. The result of housewife's attitude shows enough attitude at $75.5 \%$, good $20.8 \%$ and less $3.8 \%$. For the results of housewife's behavior reveals enough behavior $58.5 \%$, less $34.9 \%$, and good $6.6 \%$. The results showed that the knowledge level, attitude, and behavior of housewives in the Batubulan Village, Sukawati District, Gianyar Regency about mosquito nests eradication reveals enough. Therefore, counseling about mosquito nests eradication activities should be done to improve knowledge, attitude and behavior of housewives.

Keyword : Knowledge, Attitude and Behavior, Eradication.
\end{abstract}

\section{Introduction}

Dengue is an important public health problem in the tropics and subtropics regions in the world. Dengue is an endemic disease in Indonesia whose number of sufferers continues to increase from year to year and the spread is even wider. The large number of sufferers and control costs make DHF a major public health problem [1]. The number of dengue cases that occur is very large, an estimated 50 million infections per year occur in around 100 countries. In 2015 there were 126,675 dengue sufferers in 34 provinces in Indonesia, and 1,229 of them died. This number is higher than in the previous year, in 2014 there were 100,347 DHF sufferers and as many as 907 of them died [1,2].

The province with the highest DHF morbidity in 2015 was Bali [2] The cases of dengue fever in Bali in 2015 were reported as many as 10,757 cases with the number of deaths of 29 people, an increase compared to 2014, in which there were 8,629 cases with the number of deaths of 17 people. Gianyar regency has the highest number of dengue cases with 2,198 cases followed by Badung with 2,178 cases, 2,007 cases in Buleleng, 1,574 cases in Denpasar City, 846 cases in Tabanan, 790 cases in Karangasem, 451 cases in Klungkung, 366 cases in Jembrana and Bangli with 347 cases. The number of dengue cases continues to increase in Gianyar Regency. In 2013 there were 808 cases in Gianyar, in 2014 there were 1,763 cases 
and in 2015 there were 2,198 cases. From the data from Gianyar Regency General Hospital, DHF is the highest number of hospitalization cases in 2015 [3].

DHF can be suffered by all age groups of children, adolescents and adults [4]. The easiest yet effective way to prevent dengue is through PSN as it costs only a little and immediately break the chain of the mosquito life cycle, while the activity fumigation (fogging) only eradicate adult mosquitoes without breaking the chain of the mosquito life cycle [5]. Community participation in eradicating dengue mosquito nests should be prioritized, especially the role of housewives because they are responsible for taking care of the household, including the cleanliness of the house [6]. The aim of the study was to identify the level of knowledge, attitudes, and behavior of housewives regarding eradication of mosquito nests in Gianyar Regency.

\section{Method}

The study was conducted in Batubulan Village, Sukawati District, Gianyar Regency in 2017 for three months. This research is a descriptive study using cross sectional approach. The sample of this study was housewives in Batubulan Village, Sukawati Subdistrict, Gianyar Regency who were determined by the Multistage Random Sampling method.

The variables in this study were the level of knowledge, attitudes and behavior of housewives regarding eradication of mosquito nests. Data collection is done using a questionnaire. Purpose of the study was explained at first to the respondents while at the same time asking for approval from the respondents. Before analyzing the data, data processing was performed first through the process of editing, coding, scoring, tabulating and analysis.

Furthermore, the data in this study will be displayed in the form of tables and narratives.

\section{Results And Discussion}

Table 1. Characteristic of Respondents

\begin{tabular}{clcc}
\hline No & \multicolumn{1}{c}{ Variable } & Frequency & Percentage \\
\hline 1 & Age & 25 & \\
& 21-30 y.o & 35 & 26.0 \\
& 31-40 y.o & 32 & 36.6 \\
& 41-50 y.o & 4 & 33.3 \\
& $>50$ y.o & & 4.1 \\
2 & Sex & 78 & 81.2 \\
& Male & & 18 \\
& Female & & \\
Education Background & 4 & 3.8 \\
& Uneducated & 13 & 12.3 \\
& Elementary School & 18 & 17.0 \\
& Junior High School & 50 & 52.1 \\
& Senior High School & & 25 \\
& Bachelor Degree & & \\
Occupation & 54 & 50.9 \\
& Housewife & 24 & 22.6 \\
\hline
\end{tabular}




\begin{tabular}{llcc}
\hline No & \multicolumn{1}{c}{ Variable } & Frequency & Percentage \\
\hline & Merchant & 9 & 8.5 \\
& Civil Servant & 19 & 17.9 \\
\hline
\end{tabular}

Characteristics of respondents, as shown in table 1 were obtained through interviews in the form of questionnaires to 106 housewives in Batubulan Village, Sukawati District, Gianyar Regency. Most respondents came from the age of 41-50 years with 44 people (41.5\%), followed by ages $31-40$ years with 36 people (34\%), ages between $21-30$ years with 15 people $(14.2 \%)$ and ages above 50 years with 11 people $(10.4 \%)$. Most of the respondents who only worked as housewives were 54 people $(50.9 \%)$, then private workers with 24 people $(22.6 \%)$, civil servants with 19 people (17.9\%), and traders with 9 people (8.5\%). Most of the respondents were high school educated with 46 people $(43.4 \%)$. Then 25 respondents with tertiary education $(23.6 \%), 18$ respondents with junior high school education (17\%), 13 respondents with elementary school education (12.3\%), and 4 respondents with no educational background $(3.8 \%)$.

Based on table 2, it can be seen that the level of knowledge of housewives regarding eradication of mosquito nests is mostly included in the 'sufficient' category (50.9\%), some are in the 'less' category (29.2\%) and the rest are in the 'good' category (19.8\%). Based on table 2 , it can be seen that the attitude of housewives on eradicating mosquito nests is mostly included in the 'sufficient' category (75.5\%), some of which are in the 'good' category $(20.8 \%)$ and the rest are in the 'less' category $(3.8 \%)$. Based on table 3 , it can be seen that the behavior of housewives regarding eradication of mosquito nests is mostly in the 'sufficient' category $(58.5 \%)$, some of them fall into the less category $(34.9 \%)$ and the rest are in the 'good' category $(6.6 \%)$.

Table 2. Level of Knowledge, Attitude, and Behavior of Respondents

\begin{tabular}{clcc}
\hline No & \multicolumn{1}{c}{ Variable } & Frequency & Percentage \\
\hline 1 & Knowledge & 21 & \\
& Good & 54 & 19.8 \\
& Sufficient & 31 & 50.9 \\
& Bad & & \\
2 & Attitude & 20 & 20,8 \\
& Good & 80 & 75.5 \\
& Sufficient & 4 & \\
& Bad & & \\
& Behavior & & 6.6 \\
& Good & 7 & 58.5 \\
& Sufficient & 62 & \\
\hline & Bad & 37 &
\end{tabular}

Knowledge is the result of human sensing, or the result of one's knowing of an object through one's senses [7]. The level of respondents' knowledge is the ability of respondents to answer questionnaires regarding eradication of mosquito nest. Having seen the respondent's answers to each statement, the most correctly answered question by the respondent is regarding the places for breeding of dengue mosquitoes conducted by PSN. This question is answered correctly by as many as 75 people (70.8\%). And the most incorrectly answered question by respondents was about the breeding grounds for dengue-spreading mosquitoes with 49 people (46.2\%). Respondents still think that mosquitoes that are causing dengue prefer to live in dirty water, in fact however, DHF mosquitoes relatively prefer clean water as a place 
to live and breed [8]. This is consistent with the results of Sidiek's research in 2012 at Dr. Kariadi Hospital Semarang. Another question that was also answered incorrectly by respondents was about the clinical symptoms of DHF with 47 people (44.3\%). This is in accordance with the results of Kitu's research in 2014 in Pedungan Village, South Denpasar District $[9,10]$. This is because the initial clinical symptoms of DHF is a sudden fever which lasts for a quite long time similar to the description of other infectious diseases [11].

Overall the results of this study show similarities with the results of research conducted by Ganie in 2009 in Medan with a total sample of 99 people. In the aforementioned research, the results found were that the level of knowledge of the community there were mostly included in the 'sufficient' category of $54.5 \%$ [11]. However, the results of this study also show differences with the results of research conducted by Kitu in 2014 in Pedungan Village, South Denpasar District with a total sample of 60 people. In this research, it was found that the level of knowledge of the community there was mostly included in the 'good' category' of $75 \%$ and other was included in the 'sufficient' category of $25 \%$; although in terms of education respondents show similarity, namely high school education level [10]. The causes of differences in the results of this study are in accordance with previous theory which states the level of knowledge is not only influenced by education but is also influenced by other sources of information such as television, newspapers, magazines and the internet. In addition, there are other factors that also influence the level of knowledge, including social culture and economy, the influence of the environment and one's experience [7].

Attitude is an individual response to an or all objects and situations that produce action on the basis of that response, so that attitude becomes the tendency of respondents to behave, where in its determination will be strongly influenced by the thoughts, beliefs and emotions of the respondents [12]. The attitude referred to in this study is the reaction or response of respondents to the handling and prevention of dengue through mosquito breeding activities. Based on the respondents' answers to each question, the question that was most correctly answered by the respondents regarding the implementation of mosquito's nest eradication activities is the role and responsibility of the government. Respondents who answered 'disagree' were 46 people (43.4\%) and those who answered 'strongly disagree' were people $(42.5 \%)$.

Behavior is the result of all kinds of experiences and human interactions with the environment that are manifested in the form of knowledge, attitudes and actions [13]. Respondent's behavior is everything that the respondent has done in connection with the handling and prevention of dengue through the eradication of mosquito breeding activities. Having seen the respondent's answer in each question, a statement that is acknowledged to be carried out by most respondents, namely as many as 91 people $(85.8 \%)$, is regarding their habit of throwing used items such as cans directly into the trash. The community does not yet have the awareness that just collecting and putting garbage in the trash can is not enough to avoid the risk of mosquitoes breeding in cans, buckets and other used goods. Because cans, buckets and other used goods can still be a breeding place for dengue mosquitoes if they can still hold clean water or rainwater when disposed. If the items are to be disposed of, it should be given a cover or the position of disposal should be upside down so that it is not risky to collect water again [14]. This finding was followed by a statement about mosquito nest's eradication worker activities which was conducted at least once a week and was carried out by as many as 88 people $(83 \%)$. Overall the results of this study show similarities with previous research conducted in Semarang. In the aforementioned research, it was found that the behavior of the people there were mostly included in the 'sufficient' category of $75.8 \%$ [9]. However, the results of this study also show differences with the research conducted by Kitu 
in 2014 in Pedungan Village, South Denpasar District with a total sample of 60 people. In the aforementioned research, it was found that the behavior of the community there were mostly included in the 'good' category of $55 \%$ and those that were included in the 'sufficient' category only of $45 \%$ [10]. This difference in results is in accordance with the theory which states that behavior shows a response or reaction to external stimuli, but the response produced depends on the characteristics and other factors of the person concerned [15].

\section{Conclusions}

The ability of Science Teachers in the implementation of 2013 Curriculum in one of Yogyakarta State Junior High Schools, to plan lesson plans based on the 2013 curriculum is basically very good. a teacher in one of Yogyakarta State Junior High Schools plans in advance so that learning can run actively and creatively in developing learning tools according to the themes they teach, guidelines in implementing learning using RPP that are made according to syllabus that have been set according to the 2013 curriculum and for one theme in planning as well as assessment and learning tools included in making weekly plans. The stage of implementing learning is carried out in the classroom with an interactive atmosphere according to the creativity of the teacher who teaches, so students become creative and innovative in thinking. Then in evaluating teachers use class-based evaluations that fit the 2013 curriculum, such as: written tests, test tests, attitude assessments, and authentic assessments in the form of task assignments and portfolio activities. It can be concluded that the support of a school principal in providing opportunities for teachers to understand the curriculum can have a good impact so that being a teacher can be creative and make it easier for students to more easily understand learning.

\section{References}

[1] Simmons C P, Farrar J J, Chau N V V, Wills B 2012 Current Concept of Dengue The New England Journal of Medicine 366(1) p1423-1432.

[2] Kementerian Kesehatan Republik Indonesia 2015 Kasus DBD 2015 (Jakarta - Kementerian Kesehatan Republik Indonesia.

[3] Dinas Kesehatan Kabupaten Gianyar 2016 Profil Kesehatan Kabupaten Gianyar Tahun 2015 (Gianyar - Dinas Kesehatan Kabupaten Gianyar).

[4] Schimidt A C 2010 Response to Dengue Fever - The Good, the Bad, and the Ugly? The New England Journal of Medicine 5(1) p484-487.

[5] Vythilingam I, Wan Yusoff W S 2017 Review Article Dengue Vector Control in Malaysia: Are We Moving in the Right Direction Tropical Biomedicine 34(4) p746-758.

[6] Zahir A, Ullah A, Shah M, Mussawar A 2016 Community Participation, Dengue Fever Prevention, and Control Practice Int. J. Mch. AIDS 5(1) p39-45.

[7] Schwarz N, Bohner G 2001 The Construction of Attitudes (Oxford - Blackwell Publishing).

[8] World Health Organization 2009 Dengue: Guidelines for Diagnosis, Treatment, Prevention, and Control. Special Programme for Research and Training in Tropical Diseases 1(1) p3-147.

[9] Sidiek A 2012 Hubungan Tingkat Pengetahuan Ibu Mengenai Penyakit DBD terhadap Kejadian Penyakit DBD pada Anak (Semarang - Universitas Diponegoro). 
[10] Kitu A 2014 Tingkat Pengetahuan, Sikap, dan Perilaku Ibu Rumah Tangga Mengenai Demam Berdarah Dengue dan Pemberantasan Sarang Nyamuk di Banjar Dukuh Pesirahan Desa Pedungan (Denpasar - Universitas Warmadewa).

[11] Kalayanarooj S 2011 Clinical Manifestations and Management of Dengue/DHF/DSS Trop. Med. Health 39(4 Suppl.) p83-87.

[12] Howe L C, Krosnick J A 2017 Attitude Strength Annu. Rev. Psychol 68 p327-351

[13] Institute of Medicine (US) Committee on Health \& Behavior: Research, Practice, \& Policy 2001 Health \& Behavior: The Interplay of Biological, Behavioral, and Social Influences (Washington DC - National Academic Press).

[14] Getachew D, Tekie H, Gebre-Michael T, Balkew M, Mesfin A 2015 Breeding Sites of Aedes aegypti: Potential Dengue Vectors in Dire Dawa, East Ethiopia Inter. Discip. Perspect. Infect. Dis. 706276.

[15] Harisson L A, Ahn C, Adolphs R 2015 Exploring the Structure of Human Defensive Responses from Judgements of Threat Scenarios pLoS On 10(18): e0133682 